\title{
Towards an ideal source of mesenchymal stem cell isolation for possible therapeutic application in regenerative medicine
}

\author{
Maurizio Bellavia ${ }^{\mathrm{a}, \mathrm{e}}$, Roberta Altomare ${ }^{\mathrm{a}, \mathrm{b}}$, Francesco Cacciabaudo ${ }^{\mathrm{a}, \mathrm{b}}$, Alessandra Santoro ${ }^{c}$, Adolfo Allegrad, \\ Maria Concetta Giovialea, Attilio Ignazio Lo Monte ${ }^{\mathrm{a}, \mathrm{b}}$
}

Background. The possibility of obtaining mesenchymal stem cells (MSCs) from fetal tissue such as amniotic fluid, chorionic villi and placenta is well-known and a comparison between MSCs originating in different sources such as fetal tissue and those from bone marrow in terms of yield and function is a topical issue. The mesenchymal stem cells isolated from bone marrow are well-characterized. Unfortunately the low quantitative yield during isolation is a major problem. For this reason, other tissue sources for MSCs are of paramount importance.

Conclusion. In this review, starting from a description of the molecular and cellular biology of MSCs, we describe alternative sources of isolation other than bone marrow. Finally, we describe the potential therapeutic application of these cells.

Key words: mesenchymal stem cells, stem cell markers, regenerative medicine

Received: December 21, 2012; Accepted with revision: June 27, 2013; Available online: July 29, 2013

http://dx.doi.org/10.5507/bp.2013.051

${ }^{a}$ Dipartimento di Discipline Chirurgiche ed Oncologiche (DICHIRON), Universita degli Studi di Palermo, Palermo, Italy

${ }^{b}$ Dottorato di Ricerca in Biotecnologie Chirurgiche e Medicina Rigenerativa nell'Insufficienza d'Organo, Universita degli Studi di Palermo,

Palermo, Italy

'Laboratorio di Diagnostica Integrata Oncoematologica e Manipolazione Cellulare, Azienda Ospedali Riuniti Villa Sofia - V. Cervello, Palermo, Italy

${ }^{d}$ ANDROS-Day Surgery e Medicina della Riproduzione, Palermo, Italy

eIstituto Euro-Mediterraneo di Scienza e Tecnologia (I.E.ME.S.T.), Palermo, Italy

Corresponding author: Roberta Altomare, e-mail: roberta.altomare@unipa.it

\section{THE SPECIFIC CELLULAR AND MOLECULAR BIOLOGY OF MSCs}

Mesenchymal stem cells (MSCs) are stromal cells with a fibroblastoid morphology, capable of growing adherent to plastic in culture ${ }^{1}$.

The expression of specific surface antigens can distinguish MSCs from other cell types and hematopoietic stem cell markers CD105, CD90, CD73, CD44, CD29 and $\mathrm{CD} 13$ are the most common antigens expressed by MSCs which are instead negative for all hematopoietic markers including CD34, CD45, CD11b, CD33, CD117 and HLA-DR (ref., ${ }^{2,3}$ ).

Regarding gene expression, all MSCs express embryonic markers such as Oct-4, Nanog and Sox-2; the expression of these factors is crucial for maintaining transcriptional self-renewal and pluripotency ${ }^{4}$ (Fig. 1).

In embryonic stem cells, Oct-4 plays, for example, a central role in maintaining self-renewal and differentiation into specific cell lines ${ }^{5}$. A decreased expression of Oct-4 induces differentiation into cell types of the extraembryonic trofoectoderma. In contrast, an increased expression leads to differentiation into mesoderm and endoderm. Finally no expression of Oct-4 causes developmental arrest of the embryo itself ${ }^{6}$.

Another feature used to distinguish MSCs is their ability to differentiate in vitro into several mesenchymal cell lines such as osteoblasts, chondrocytes and adipocytes ${ }^{2}$ after administration of growth factors or when cultured in media supplemented with dexamethasone and ascorbate $^{7-11}$.

\section{LOOKING FOR A SUITABLE SOURCE OF SUPPLY OF MSCs}

\section{Adipose tissue}

In clinical practice, the main source of MSCs is adult bone marrow. However, harvesting of bone marrow mesenchymal cells is beset by several problems: it is difficult to access and it involves the use of invasive techniques. The percentage of MSCs in the bone is very low (0.001$0.01 \%$ ) and it decreases with ageing ${ }^{12}$. For these reasons it is important to find alternative sources of MSCs.

A possible alternative source of mesenchymal stem cells is adipose tissue which offers a greater number of cells and is easily accessible ${ }^{2}$. Adipose tissue-derived cells are applicable for soft tissue repair and used in the clinic for the coating of scaffolds, in breast augmentation surgery and in fistula repair. Many other applications are under clinical trials ${ }^{13}$. 


\section{Fetal tissues}

Fetal tissues represent a new alternative source of mesenchymal stem cells. They can be isolated from the fetus itself or from extraembryonic structures like umbilical cord, amniotic fluid, the Wharton's jelly, the chorionic villi and placenta ${ }^{14}$.

Many studies indicate that stem cells derived from these new sources have features both of pluripotent embryonic stem cells and multipotent adult stem cells ${ }^{15}$. Hematopoietic stem cells isolated from umbilical cord, for example, are well characterized, and their application in transplantation, especially in children, is well documented $^{16}$. The non-hematopoietic cells from umbilical cord blood are instead a recent discovery. These cells grow in adhesion in vitro in the absence of cytokines or growth factors for more than ten cell passages, showing a CD34 negative, CD45 negative immunophenotype. These cells form fibroblast-like colonies and have features comparable to adult mesenchymal stem cells ${ }^{15}$. The amount of MSCs isolated from umbilical cord blood is about 20\% of the total, probably because few of these cells go into the bloodstream ${ }^{17}$.

\section{Wharton's jelly}

The Wharton's jelly is the outer part of the umbilical cord and is composed of umbilical cord matrix stem cells, umbilical cord perivascular cells and stromal umbilical cord blood cells ${ }^{14}$. The cells with greater proliferative potential are located at the interface with the amniotic fluid, while the fibroblast-like cell types are close to blood vessels ${ }^{18}$. Stem cells isolated from Wharton's jelly have a typical expression profile of adult mesenchymal cells and they are able to differentiate into adipocytes, chondro- cytes, osteocytes, cardiomyocytes and neurons ${ }^{19}$. These cells also express embryonic stem cells markers such as Oct-4, Sox-2, Nanog and Rex-1 (ref. ${ }^{20,21}$ ).

\section{Amniotic fluid}

The amniotic fluid is usually used for prenatal diagnosis through amniocentesis but recently its potential as a source of stem cells has been highlighted. The population of cells obtained from amniotic fluid is heterogeneous, in fact it is derived from all three germ layers and it contains several partially differentiated cell types; the main cell type is the epithelial one. Tsai et al. ${ }^{22}$ developed a protocol for isolation and expansion of stem cells from amniotic fluid samples at second trimester of pregnancy, in particular between the sixteenth and twentieth week. These cells are positive for CD105 and CD90 antigens, but negative for hematopoietic antigens. In addition, they express Oct-4 (ref. ${ }^{23}$ ) and they are able to differentiate into osteocytes $^{24}$, adipocytes and neuronal cells ${ }^{25}$. All together these features strongly suggest that amniotic fluid-derived stem cells are MSCs.

Other studies have confirmed and extended these data, revealing the positivity of amniotic fluid cells for other embryonic markers including SSEA-4 and Nanog. In addition the expression of Oct-4 maintains high levels up to twenty culture passages demonstrating the ability of these cells to maintain the undifferentiated state for a long time ${ }^{26}$.

The amniotic stem cells can be cultured for over eight months, maintaining a high rate of proliferation, with a doubling time of about $36 \mathrm{~h}$ without degradation of karyotype ${ }^{27}$.

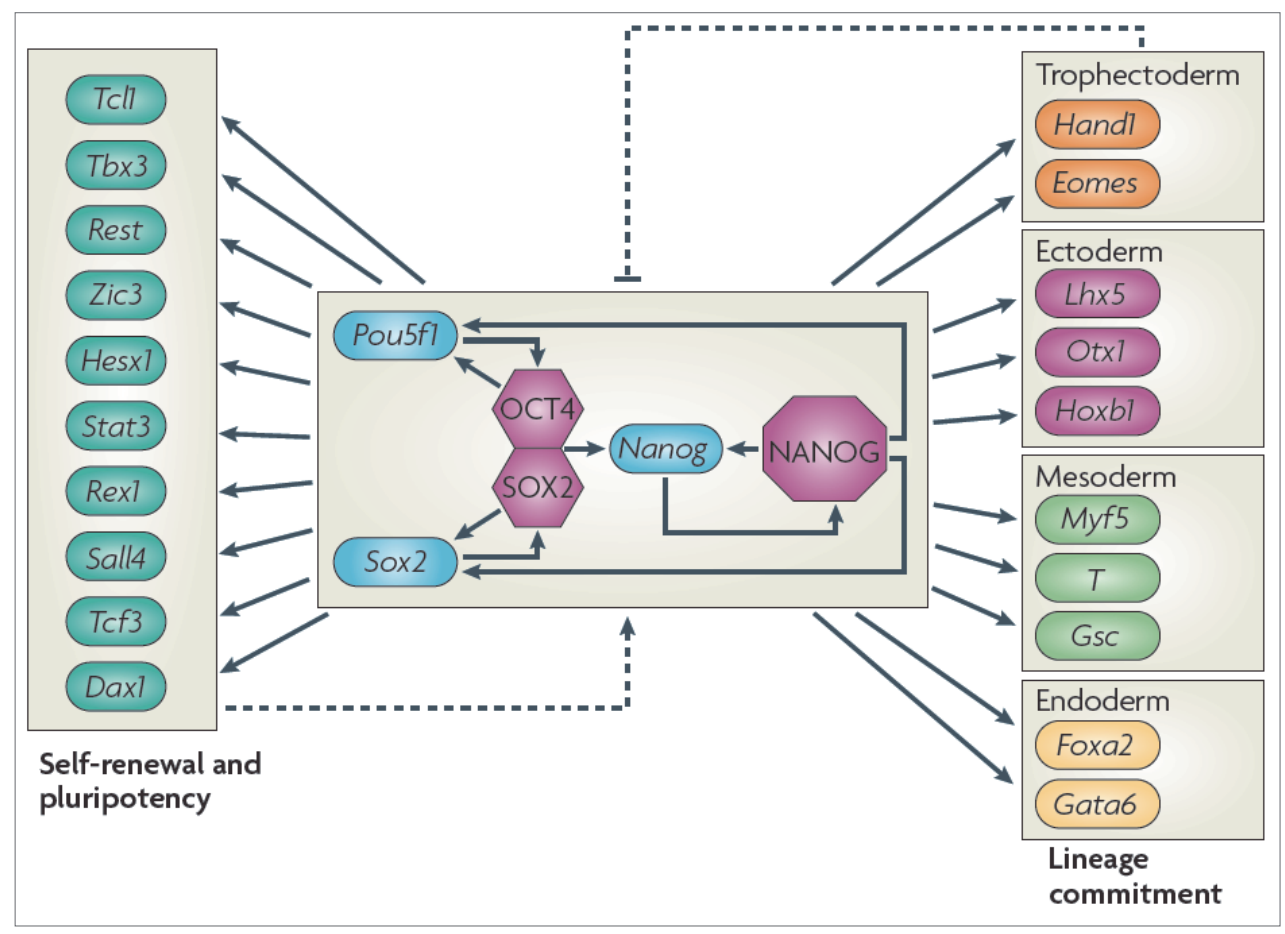

Fig. 1. Schematic representation of the transcriptional circuit of mesenchymal stem cells. (Modified from Ben D. MacArthur et al. Systems biology of stem cell fate andcellular reprogramming. Nature Review Molecular Cell Biology 2009;10,672-81. doi:10.1038/nrm2766). 
Unfortunately, the great therapeutic potential of the amniotic fluid-derived cells is greatly undermined by in vivo experiments which showed a lack of capacity of differentiation, implying the request of reprogramming ex vivo ${ }^{14}$.

\section{Amniotic membrane}

The amniotic membrane, or amnion, contains a stem cell population. This membrane, without blood vessels, results from the epiblast eight days after fertilization and consists of three parts: an insert of epithelial cells called amniotic epithelial cells, a cell-free intermediate and an exterior part, juxtaposed to the chorion, which contains amniotic mesenchymal cells ${ }^{28}$.

Since these cells originate from epiblast, it is reasonable that they have features of embryonic stem cells. Recent studies have shown that these features are restricted to the population of amniotic epithelial cells ${ }^{29}$.

\section{Chorionic villi}

The disintegration of the chorionic villi, obtained by chorionic villus sampling for prenatal analysis, allows to isolate a cell population with fusiform morphology. Poloni et al. ${ }^{29}$ characterized a population of cells positive for mesenchymal surface antigens as CD105, CD90, CD73, CD44, CD29 and CD13, but negative for hematopoietic ones. The undifferentiated state of this cell population is shown by the expression of several stem cell markers as Oct-4, Rex-1, GATA-4 and nestin. The chorionic villi cells are also able to differentiate into osteocytes, adipocytes, chondrocytes and neuronal cells, they have a high proliferative potential and undergo alterations in karyotype ${ }^{30}$.

\section{Placenta}

In addition to supporting fetal development, the placenta is an important reserve of stem and progenitor cells.

The placenta is a maternal-fetal organ that originates from the trofoectoderma and includes parts of cytotrophoblast and syncytiotrophoblast ${ }^{31}$. The populations of stem cells derived from placenta can be divided in chorionic trophoblast cells and chorionic mesenchymal cells; both populations show remarkable plasticity ${ }^{32}$. Recent studies have demonstrated the presence of stem cells also in the mother's side of the placenta, the decidua, isolated at the time of delivery. These cells express stem cell markers as SSEA-4, SSEA-1, Nanog, Rex-1 and Oct-4 (ref. ${ }^{33}$ ).

MSCs isolated from placenta showed features comparable to those isolated from bone marrow ${ }^{14}$. These placenta-derived cells seem to be able to differentiate into endothelial cells as well as mesenchymal cells, suggesting the existence of resident endothelial progenitors during embryonic development ${ }^{34}$.

Furthermore, it appears that the tissues of the placenta located between the vitelline yolk and aorta are an independent site for the regeneration of CD34+ hematopoietic stem cells ${ }^{35}$, which together with the CD31+ and CD133+ endothelial progenitors, support angiogenesis in the fetus ${ }^{34}$.

\section{POSSIBLE THERAPEUTIC APPLICATIONS OF MSCs}

Thanks to their properties, the use of MSCs could represent a breakthrough in regenerative medicine. Mesenchymal stem cells are easily isolated from the donor, can be expanded in culture maintaining genetic stability, are little immunogenic and thus suitable for allogeneic transplants ${ }^{36,37}$.

The potential of mesenchymal stem cells goes beyond the conventional differentiation in different cell lines and it includes the mesodermal cells differentiation into liver, kidney, muscle, epithelial, neuronal and cardiac cells ${ }^{38,39}$. More than 120 clinical trials are in progress, using stem cells for different therapeutic applications. So far they find application in the repair of bone and cartilage or in immunomodulation which takes advantage of the immunosuppressive capacity of $\mathrm{MSCs}^{37}$ which are able to inhibit the T-lymphocytes, probably through the production of nitric oxide ${ }^{40}$, counteracting Graft versus Host Disease ${ }^{41,42}$. It is not yet enough clear the molecular mechanism by which MSCs exert their immunomodulatory properties, but it is interesting to note that these cells have both immunosuppressive capacity and the ability to trigger the immune response.

In vivo, MSCs seem to be able to migrate into damaged tissues (homing) (ref. ${ }^{43}$ ) and to repair them differentiating into tissue-specific phenotypes, or favoring the repair triggered by endogenous cells $\mathrm{s}^{44}$; it has also been proposed that bone marrow-derived mesenchymal stem cells could exert a crucial role in kidney transplant outcome ${ }^{45}$. The migration ability of MSCs allows to administer them intravascularly, in a non-invasive way ${ }^{46}$. Mesenchymal stem cells are able to migrate into ischemic tissues in a chemiotaxis-driven way, proliferating and differentiating into specific cellular types ${ }^{47}$. These abilities make them suitable for the treatment of damage caused by ischemia such as myocardial infarction or cerebral ischemia ${ }^{48}$.

In vitro studies have shown that MSCs can be induced to differentiate into cardiomyocytes ${ }^{49}$ even if, in vivo, the beneficial effect of MSCs seems to result from the secretion of cytokines in the environment surrounding the lesion rather than from their differentiation. MSCs can also differentiate into neural cellular types in the presence of EGF (Epidermal Growth Factor) and BDNF (Bone Derived Neurotrophic Factor) and they have the ability to increase the proliferation of indigenous neural stem cells $^{50}$.

In vivo studies have shown that therapy based on the use of MSCs restores blood flow and the integrity of the blood-brain barrier following cerebral ischemic injury ${ }^{51}$.

\section{CONCLUSION}

MSCs could be suitable for several applications in regenerative medicine. For this reason it is important to find novel sources that can offer an abundance of cells in a non invasive manner. MSCs derived from fetal append- 
ages could represent a good alternative compared to bone marrow ones. According to our current research, it was not a surprise that the evidence that MSCs isolated from fetal appendages when cultured show a higher proliferation rate than those isolated from bone marrow. What is surprising is that MSCs isolated from bone marrow, despite being adult cells, show phenotypic features and gene expression profile perfectly comparable to fetal stem cells. MSCs isolated from different sources are comparable to each other and therefore can be considered an alternative for research and clinical applications. However, these cells tend to reflect their origin, particularly those isolated from amniotic fluid; another important issue to be addressed is the high heterogeneity of the samples which usually contain different cell types.

More studies have to be conducted for well-characterized stem cells from fetal appendages and, in our opinion, the future goal could be isolation and characterization mesenchymal stem cells from placenta, the only source of mesenchymal stem cells that can be exploited in a completely non-invasive way, being a discarded tissue at the moment of birth.

\section{ACKOWLEDGEMENT}

Authorship contributions: MB, AR, FC: literature search; MB, AR: manuscript writing; AR, AA, AS: study design; MB, AR: data collection; AR, FC, MCG, AA, AS: data analysis; MB, AR, AILM: data interpretation; AILM: final approval.

All the authors would like to thank and remember Maurizio Bellavia who unfortunately has gone too soon. Conflict of interest statement: None declared.

\section{REFERENCES}

1. Dominici M, Le Blank K, Mueller, Slaper-Cortenbach I, Marini F, Krause D, Deans R, Keating A, Prockop Dj, Horwitz E. Minimal criteria for defining multipotent mesenchymal stromal cells. The International Society for Cellular Therapy position statement. Cytotherapy 2006;8(4):315-7.

2. Rastegar F, Shenaq D, Huang J, Zhang W, Zhang BQ, He BC, Chen L, Zuo GW, Luo Q, Shi Q, Wagner ER, Huang E, Gao Y, Gao JL, Kim SH, Zhou JZ, Bi Y, Su Y, Zhu G, Luo J, Luo X, Qin J, Reid RR, Luu HH, Haydon RC, Deng ZL, He TC. Mesenchymal stem cells: Molecular characteristics and clinical applications. World Journal of Stem Cells 2010;2(4):67-80.

3. Trounson A, Thakar RG, Lomax G, Gibbons D. Clinical trials for stem cell therapies. BMC Medicine 2010;9:52. doi: 10.1186/1741-7015-952

4. Fujita T, Azuma Y, Fukuyama R, Hattori Y, Yoshida C, Koida M, Ogita K, Komori T. Runx 2 induces osteoblast and chondrocyte differentiation and enhances their migration by coupling with PI3K-Akt signalling. Journal of Cell Biology 2004;166(1):85-95.

5. Babu MM, Luscombe NM, Aravind L, Gerstein M, Teichmann SA. Structure and evolution of transcriptional regulatory networks. Current Opinion in Structural Biology 2004;14(3):283-91.

6. Pardo M, Lang B, Yu L, Prosser H, Bradley A, Babu MM, Choudhary J. An Expanded Oct4 Interaction Network: Implications for Stem Cel Biology, Development, and Disease. Cell Stem Cell 2010;6(4):382-95.

7. Pittenger MF, Mackay AM, Beck SC, Jaiswal RK, Douglas R, Mosca JD, Moorman MA, Simonetti DW, Craig S, Marshak DR. Multilineage potential of adult human mesenchymal stem cells. Science 1999;284(5411):143-7.
8. Farmer SR. Regulation of PPARgamma activity during adipogenesis. International Journal of Obesity 2005;29 Suppl 1:S13-6.

9. Oishi K, Noguchi H, Yukawa H, Hayashi S. Differential ability of somatic stem cells. Cell Transplant 2009;18(5):581-9.

10. Akiyama, H. Control of chondrogenesis by the transcription factor Sox9. Modern Rheumatology 2009;18(3):213-9.

11. Choi YH, Burdick MD, Strieter RM. Human circulating fibrocytes have the capacity to differentiate osteoblast and chondrocytes. Int J Biochem Cell Biol 2010;42(5):662-71.

12. Mihu CM, Mihu D, Costin N, Rus Ciucă D, Suşman S, Ciortea R. Isolation and characterization of stem cells from the placenta and the umbilical cord. Romanian journal of Morphology and Embryology 2010;9(4):441-6.

13. Pappa KI, Anagnou NP. Novel sources of fetal stem cells: where do they fit on the delovpmental continuum? Regenerative Medicine 2009;4(3):423-33.

14. Pojda Z, Machaj EK, Oldak T, Gajkowska A, Jastrzewska M. Nonhematopoietic stem cells of fetal origin-how much of today's enthusiasm will pass the time test? Folia Histochemica et Cytobiologica 2005;43(4):209-12.

15. Bieback K, Brinkmann I. Mesenchymal stromal cells from human perinatal tissues: From biology to cell therapy. World Journal of Stem Cells 2010;2(4):81-92.

16. Takechi K, Kuwabara Y, Mizuno M. Ultrastructural and immunohistochemical studies of Wharton's jelly umbilical cord cells. Placenta 1993;14(2):235-245.

17. Wang HS, Hung SC, Peng ST, Huang CC, Wei HM, Guo YJ, Fu YS, Lai MC, Chen CC. Mesenchymal stem cells in the Wharton's jelly of the human umbilical cord. Stem Cells 2004;22(7):1330-7.

18. Conconi MT, Burra P, Di Liddo R, Calore C, Turetta M, Bellini S, Bo P, Nussdorfer GG, Parnigotto PP. CD105+ Cells from Wharton's jelly show in vitro and in vivo myogenic differentiation potential. International Journal of Molecular Medicine 2006;18(6):1089-96.

19. Sakuragawa N, Thangavel R, Mizuguchi M, Hirasawa M, Kamo I. Expression of markers for both neuronal and glial cells in human amniotic epithelial cells. Neuroscience Letters 1996;209(1):9-12.

20. Prusa AR, Marton E, Rosner M, Bernaschek G, Hengstschlager M. Oct-4-expressing cells in human amniotic fluid: a new source of stem cell research? Human Reproduction 2003;18(7):1489-93.

21. Carlin R, Davis D, Weiss M, Schultz B, Troyer D. Expression of early transcription factors Oct4, Sox2 and Nanog by porcine umbilical cord (PUC) matrix cells. Reproductive Biology and Endocrinology 2006;4:8.

22. Tsai MS, Lee JL, Chang YJ, Hwang SM. Isolation of human multipotent mesenchymal stem cells from second-trimester amniotic fluid using a novel two-stage culture protocol. Human Reproduction 2004;19(6):1450-6.

23. Kim J, Lee Y, Kim H, Hwang KJ, Kwon HC, Kim SK, Cho DJ, Kang SG, You J. Human amniotic fluid-derived stem cells have characteristics of multipotent stem cells. Cell Proliferation 2007;40(1):75-90.

24. Antonucci I, lezzi I, Morizio E, Mastrangelo F, Mastrangelo F, Pantalone A, Mattioli-Belmonte M, Gigante A, Salini V, Calabrese G, Tetè S, Palka G, Stuppia L. Isolation of osteogenic progenitors from human amniotic fluid using a single step culture protocol. BMC Biotechnology 2009; 9:9.

25. Roubelakis MG, Pappa KI, Bitsika V, Zagoura D, Vlahou A, Papadaki HA, Antsaklis A, Anagnou NP. Molecular and proteomic characterization of human mesenchymal stem cells derived from amniotic fluid: comparison to bone marrow mesenchymal stem cells. Stem Cell and Development 2007;16(6):931-52.

26. Ilancheran S, Michalska A, Peh G, Wallace EM, Pera M, Manuelpillai U. Stem cells derived from human fetal membranes display multilineage differentiation potential. Biology of Reproduction 2007;77(3):577-88.

27. Miki T, Strom SC. Amnion-derived pluripotent/multipotent stem cells. Stem Cell Reviews and Reports 2006;2(2):133-42.

28. Hemberger M, Yang W, Natale D, Brown TL, Dunk C, Gargett CE, Tanaka S. Stem cells from fetal membranes. A Workshop Report. Placenta 2008;29(A):S17-S19.

29. Poloni A, Rosini V, Mondini E, Maurizi G, Mancini S, Discepoli G, Biasio S, Battaglini G, Berardinelli E, Serrani F, Leoni P. Characterization and expansion of mesenchymal progenitor cells from first-trimester chorionic villi of human placenta. Cytotherapy 2008;10(7):690-97.

30. Parolini O, Alviano F, Bagnara GP, Bilic G, Bühring HJ, Evangelista M, Hennerbichler S, Liu B, Magatti M, Mao N, Miki T, Marongiu 
F, Nakajima H, Nikaido T, Portmann-Lanz CB, Sankar V, Soncini M, Stadler G, Surbek D, Takahashi TA, Redl H, Sakuragawa N, Wolbank S, Zeisberger S, Zisch A, Strom SC. Isolation and characterization of cells from human term placenta: outcome of the First International Workshop on Placenta-Derived Stem Cells. Stem Cells 2008;26(2):300-11.

31. Armstrong L, Saretzki G, Peters H, et al. Overexpression of telomerase confers growth advantage, stress resistance, and enhanced differentiation of ESCs toward the hematopoietic lineage. Stem Cells 2005;23(4):516-29.

32. Strakova Z, Livak M, Krezalek M, Ihnatovych I. Multipotent properties of myofibroblasts cells derived from human placenta. Cell Tissue Research 2008;332(3):479-88.

33. Wu CC, Chao YC, Chen CN, Chien S, Chen YC, Chien CC, Chiu JJ, Linju Yen B. Synergism of biochemical and mechanical stimuli in the differentiation of human placenta-derived multipotent cells into endothelial cell. Journal of Biomechanics 2008;41(4):813-21.

34. Bárcena A, Kapidzic M, Muench MO, Gormley M, Scott MA, Weier JF, Ferlatte C, Fisher SJ. The human placenta is a hematopoietic organ during the embryonic and fetal periods of development. Developmental Biology 2009;327(1):24-33.

35. Wagner W, Wein F, Seckinger A, Frankhauser M, Wirkner U, Krause U, Blake J, Schwager C, Eckstein V, Ansorge W, Ho AD. Comparative characteristics of mesenchymal stem cells from human bone marrow, adipose tissue, and umbilical cord blood. Experimental Hematology 2005;33(11):1402-16.

36. Aggarwal S, Pittenger MF. Human mesenchymal stem cells modulate allogenic immune cell response. Blood 2005;105(4):1815-22.

37. Trounson A, Thakar RG, Lomax G, Gibbons D. Clinical trials for stem cell therapies. BMC Medicine 2011;9:52.

38. Arthur A, Zannettino A, Gronthos S. The therapeutic applications of multipotential mesenchymal/stromal stem cells in skeletal tissue repair. Journal of Cell Physiology 2009;218(2):237-45.

39. Gioviale MC, Damiano G, Palumbo VD, Bellavia M, Cacciabaudo F, Cassata G, Puleio R, Altomare R, Lo Monte Al. Pancreatic islets from non-heart-beating donor pig: Two-layer preservation method in an in vitro porcine model. International Journal of Artificial Organ 2011;34(6):519-25.

40. Sato K, Ozaki K, Oh I, Meguro A, Hatanaka K, Nagai T, Muroi K, Ozawa K. Nitric oxide plays a critical role in suppression of T-cell proliferation by mesenchymal stem cells. Blood 2007;109(1):228-34.
41. Sheng $H$, Wang $Y$, Jin $Y$, Zhang $Q$, Zhang $Y$, Wang L, Shen B, Yin S, Liu W, Cui L, Li N. A critical role of IFNgamma in priming MSC-mediated suppression of T cell proliferation through up-regulation of $\mathrm{B} 7-\mathrm{H} 1$. Cell Res 2008;18(8):846-57.

42. Kebriaei $P$, Robinson S. Treatment of graft-versus-host-disease with mesenchymal stomal cells. Cytotherapy 2011;13(3):262-8.

43. Bos C, Delmas Y, Desmoulière A, Solanilla A, Hauger O, Grosset C, Dubus I, Ivanovic Z, Rosenbaum J, Charbord P, Combe C, Bulte JW, Moonen CT, Ripoche J, Grenier N. In vivo MR imaging of intravascularly injected magnetically labeled mesenchymal stem cells in rat kidney and liver. Radiology 2004,233(3):781-9.

44. Tadokoro M, Kanai R, Taketani T, Uchio Y, Yamaguchi S, Ohgushi H. New bone formation by allogenic mesenchymal stem cell transplantation in a patient with perinatal hypophosphatasia. Journal of Pediatrics 2009;154(6):924-30.

45. Bellavia M, Gioviale MC, Damiano G, Palumbo VD, Cacciabaudo F, Altomare R, Buscemi G, Lo Monte Al. Is secondary hyperparathyroidism-related myelofibrosis a negative prognostic factor for kidney transplant outcome? Med Hypotheses 2011;77(4):557-9.

46. Chen J, Sanberg PR, Li Y, Wang L, Lu M, Willing AE, Sanchez-Ramos J, Chopp M. Intravenous administration of human umbilical cord blood reduces behavioural deficits after stroke in rats. Stroke 2001;32(11):2682-8.

47. Askari AT, Unzek S, Popovic ZB, Goldman CK, Forudi F, Kiedrowski M, Rovner A, Ellis SG, Thomas JD, DiCorleto PE, Topol EJ, Penn MS. Effect of stromal-cell-derived factor 1 on stem cell homing and tissue regeneration in ischaemic cardiomyopathy. Lancet 2003;362:697-703.

48. Amado LC, Saliaris AP, Schuleri KH, St John M, Xie JS, Cattaneo S, Durand DJ, Fitton T, Kuang JQ, Stewart G, Lehrke S, Baumgartner WW, Martin BJ, Heldman AW, Hare JM. Cardiac repair with intramyocardial injection of allogeneic mesenchymal stem cells after myocardial infarction. Proceedings of the National Academy of Science 2005;102(32):11474-79.

49. Caplan Al, Dennis JE. Mesenchymal stem cells as a trophic mediators. Journal of Cellular Biochemistry 2006;98(5):1076-84.

50. Borlongan CV, Lind JG, Dillon-Carter O, Yu G, Hadman M, Cheng C, Carroll J, Hess DC. Bone marrow grafts restore cerebral blood flow and blood brain barrier in stroke rats. Brain Research 2010;1010(12):108-16.

51. Brayfield CA, Marra KG, Rubin JP. Adipose tissue regeneration. Current Stem Cell Research and Therapy 2010;5(2):116-21. 